\title{
Legal Differentiation and the Concept of the Human Rights Treaty in International Law
}

\author{
Matthew Craven*
}

\begin{abstract}
The purpose of this article is to explore a question that is commonly posed, but infrequently answered: what is the nature of the relationship between conventional human rights law, and general principles governing treaty law? In its broadest sense the question, as posed, is part of a wider ongoing debate as to the potential 'fragmentation' of international law - a debate which has been encouraged particularly by the development of specific legal regimes with dedicated mechanisms for dispute resolution. More narrowly, the question is concerned with the compatibility of the existing treaty law framework for those legal instruments that purport to protect legal interests other than those of the contracting states. The central point of focus is upon the role and significance of reciprocity in the conceptual structure of human rights 'treaties'. It is argued that, whilst it is possible to maintain that human rights treaties are constructed on the basis of reciprocity, doing so has certain theoretical and practical costs which are not necessarily outweighed by the envisaged harm of understanding them as legal instruments possessing certain distinct characteristics.
\end{abstract}

\section{Introduction}

A subtle shift seems to have taken place in the general discourse of international law in recent years. Whereas formerly, international lawyers were concerned with the problem of establishing a credible basis for the systemic character of international law in face of the apparently optional nature of law-creation and dispute-resolution processes, ${ }^{1}$ the situation has now been reversed. No longer are we faced with the complaint that insufficient use is made of judicial forms of dispute resolution ${ }^{2}$ or that

\footnotetext{
* Reader in Law, University of London.

1 Cf. Combacau, 'Le droit international: bric-à-brac ou système?', 31 Archives de Philosophie du Droit (1986) 85.

2 On the putative 'decline' of the optional clause, see e.g. Gross, 'Compulsory Jurisdiction under the Optional Clause: History and Practice', in L. Damrosch (ed.), The International Court of Justice at a Crossroads (1987) 19.
}

EJIL (2000), Vol. 11 No. 3, 489-519 
there remain potentially significant lacunae within the law. ${ }^{3}$ Rather, the concern is that with the proliferation of international courts and tribunals ${ }^{4}$ and the rapid development of certain 'spheres' of international law, the international legal system is poised on the brink of a potentially irreversible process of fragmentation. ${ }^{5}$ The apparent variegation of law-creating processes and agencies within the international system and the diffusion of decision-making powers among a wide variety of judicial or quasi-judicial institutions all dealing with largely discrete legal regimes, does suggest that international law may be losing its centre of gravity. If it does, we may face the problem, at some stage in the future, of no longer being able to speak about 'international law' as a singular or unitary phenomenon, but only the law as it applies in certain heteronomous fields (whether that be the law of armed conflict, the law of international trade or environmental law) or as applied by certain courts or tribunals. Whatever one's prognosis of the current situation, it is clear that many of these concerns are by no means new. International lawyers have always struggled with the difficulties of transcending the contractual paradigm of treaty law and of deriving 'general law' from the existence of legal obligation in conventional form, and the current debate only places a new spin on this old problem. The difference today is simply found in the supposition that we already have a coherent 'system' of law and that we are no longer climbing the mountain, so to speak, but poised at its summit looking down.

One particular area in which the potentiality for fragmentation is frequently identified is in the field of human rights. In recent years there has been a growing appreciation that the development of human rights norms and associated processes must necessarily be reflected in the forms and structures of general international law. The concepts of erga omnes obligations and jus cogens are prime examples of developments in the structure of international law whose recognition has been informed by an overriding concern for human rights. ${ }^{6}$ The same may be said for the ILC's work in relation to state responsibility ${ }^{7}$ and state succession, ${ }^{8}$ and of the recent

3 Cf. H. Lauterpacht, 'Some Observations on the Prohibition of Non Liquet and the Completeness of the Legal Order', Symbolae Verzijl (1958) 196; J. Stone, Of Law and Nations (1974) ch. 3.

4 In the past 10 years, for example, the following bodies inter alia have begun work: the International Criminal Tribunal for Former Yugoslavia (1993); the International Criminal Tribunal for Rwanda (1995); the International Tribunal for the Law of the Sea (1996); the UN Compensation Commission (1991); the EFTA Court (1994); and the WTO Dispute Settlement Body and Appellate Body (1995). On the increased use of the ICJ, see e.g. Highet, 'The Peace Palace Hots Up: The World Court in Business Again?, 85 AJIL (1991) 646.

5 See, e.g., Charney, 'The Implications of Expanding International Dispute Settlement Systems: The 1982 Convention on the Law of the Sea', 90 AJIL (1996) 69; and Guillaume, 'The Future of International Judicial Institutions', 44 ICLQ (1995) 848.

6 Cf. Barcelona Traction, Light and Power Case, ICJ Reports (1970) 32, paras 33-34.

7 See, e.g., the extension of state responsibility to govern 'authorized' private acts (Costello-Roberts v. United Kingdom, 19 EHRR (1998) 112) or for failure to properly protect individuals against abuse (X and $Y v$. The Netherlands, ECHR (1985) Series A, No. 91). See Crawford, 'Revising the Draft Articles on State Responsibility', 10 EJIL (1999) 435, at 439-440; and more equivocally Chinkin, 'A Critique of the Public/Private Dimension', 10 EJIL (1990) 387, at 393-395.

8 See, e.g., Draft Articles on State Succession in Relation to Nationality, GAOR, 52nd Sess., Supp. No. 10 (A/52/10), chapter IV, section c. 
state practice in the field of recognition ${ }^{9}$ and intervention. ${ }^{10}$ By the same token, the development of human rights norms through the medium of specific legal regimes has, at times, led to a tension as between the subject-neutral lex generalis on the one hand and the particular demands of human rights understood as a subordinate 'subject area' on the other. This may be perceived, most clearly, in the relationship between the general principles of treaty law (encapsulated in the Vienna Convention on the Law of Treaties) and the developing practice and doctrine relating specifically to human rights treaties.

It is often suggested that the general principles governing the application and effect of treaties need to be modified, or perhaps even discarded, when dealing with the specific category of human rights treaties. ${ }^{11}$ One example of this tendency may be found in the Human Rights Committee's General Comment No. 24 in which it suggested that the classical rules on reservations embodied in the Vienna Convention were 'inappropriate' and 'inadequate' when dealing with reservations to the International Covenant on Civil and Political Rights, and that the task of determining their compatibility should rest with the Human Rights Committee itself. ${ }^{12}$ Another example to the same effect may be found in the separate opinion of Judge Weeramantry in the case concerning the Application of the Convention on the Prevention and Punishment of the Crime of Genocide ${ }^{13}$ (between Bosnia-Herzegovina and the Federal Republic of Yugoslavia). In that case, Judge Weeramantry pointed out that the question whether or not Bosnia-Herzegovina or Yugoslavia were parties to the Genocide Convention had to be answered, not simply by reference to principles governing ratification or accession, but by reference to what he understood as being the special characteristics of that Convention. He took the view that the Genocide Convention, like any 'humanitarian' treaty, did not represent an exchange of interests or benefits between contracting states, but rather embodied 'a commitment of the participating States to certain norms and values recognized by the international community ${ }^{14}$ Since the Convention imposed no burdens on the participating states, and since it therefore 'transcended' the concept of state sovereignty, it could be regarded as subject to automatic succession. ${ }^{15}$ Yugoslavia and Bosnia-Herzegovina

9 E.g., EC Guidelines on Recognition (1992). See generally Warbrick, 'Recognition of States: Part 2', 42 ICLQ (1993) 433.

10 E.g., NATO action in Kosovo. See generally Cassese, 'Ex iniuria ius oritur: Are We Moving Towards International Legitimation of Forcible Humanitarian Countermeasures in the World Community?', 10 EJIL (1999) 23; Simma, 'NATO, the UN and the Use of Force: Legal Aspects', 10 EJIL (1999) 1.

11 The argument that certain categories of treaties must be treated in a distinctive way has, of course, been a long-standing point of debate. McNair argued in 1930, for example, that we need to 'free ourselves from the traditional notion that the instrument known as the treaty is governed by a single set of rules, however inadequate, and set ourselves to study the greatly differing legal character of the several kinds of treaties and to frame rules appropriate to the character of each kind'. McNair, 'The Functions and Differing Legal Character of Treaties', 11 BYIL (1930) 100, at 106. See also Jenks, 'State Succession in Respect of Law-Making Treaties', 29 BYIL (1952) 105.

12 General Comment No. 24 (52), UN Doc. CCPR/C/21/Rev.1/Add.6, para. 17.

13 ICJ Reports (1996) 595, at 645.

14 Ibid, at $645-646$.

15 Ibid, at 649 . 
could therefore be treated as parties to the Convention whether or not they desired to be so regarded, and irrespective of the steps they may have taken to that end.

Whilst the views of Judge Weeramantry and the Human Rights Committee in each case have certainly attracted criticism, ${ }^{16}$ they do partake of a continuing, and very live debate, as to the significance of the development of specific human rights treaty 'regimes' for general international law. At one level, this debate concerns the question whether such regimes can be regarded as creating autonomous, or self-supporting, legal orders that exist independently of general international law. At another level, it is concerned with the question whether human rights treaties may be regarded as being in the nature of a 'special category' within the general corpus of international law, and, if so, how that peculiarity should be given recognition. In either case, there are several underlying issues that inform any response including, for example, the characteristics of what we might choose to call 'legal development', and the nature of our assumptions concerning the general trajectory of legal doctrine.

\section{Human Rights Treaties in International Law}

In its most general sense, international legal doctrine is characteristically diffident as to the peculiarities of human rights conventions as a specific class of treaties. The international law of human rights, as a subject, is almost universally understood as a distinct subdiscipline of the broader, more general, and apparently subject-neutral, international law. Like other 'subdisciplines' — such as environmental law, economic law or the law of the sea - human rights law may embody certain assumptions and suppositions that demand special recognition. But even whilst affirming the 'peculiarities' of such subdisciplines, legal doctrine traditionally maintains a sense of the similitude of subject areas. This is particularly true in relation to those parts of international law that are regarded as 'structural' in nature: whether that be state responsibility, state succession, custom formation or treaty law. Indeed, for international law to retain an intellectual coherence, and for it to retain the idea that it is an homogeneous 'system', it must at once recognize the diversity of subject matter (and draw fully upon that diversity) but also resist the temptation to conclude thereby that there is no 'general' law.

It has to be recognized, however, that, given its 'decentralized' nature, international law is particularly susceptible to claims of 'special consideration' and that those claims may not always be easy to dismiss. This is particularly evident in the case of human

16 As to the Human Rights Committee's General Comment, see, e.g., the observations of the UK, the US and France, 3 IHRR (1996) 261, at 265, 4 IHRR (1997) 6. The UK responded in the following terms: 'The United Kingdom does not ... believe that rules different from those foreshadowed by the International Court and in due course embodied in the Vienna Convention on the Law of Treaties are required to enable the international community to cope with reservations to human rights treaties. The correct approach is rather to apply the general rules relating to reservations laid down in the Vienna Convention in a manner which takes full account of the particular characteristics of the treaty in question.' Observations on General Comment No. 24, 3 IHRR (1996) 261, at 261-262, para. 4. 
rights treaties and not simply because of the existence of dedicated mechanisms of monitoring or enforcement, but also because in such treaties the two elements of 'form' and 'function' appear to be fundamentally at odds with one another. On the one hand, the form in which the rights are expressed - the treaty — supposes that human rights are merely the incidental subject of a contractual bargain between states. Individual 'right-holders' are therefore simply the fortuitous beneficiaries of a regime that is otherwise concerned with promoting the rights and interests of states. The teleology of the regime on the other hand - focused as it is on individual or group 'human rights' - supposes that the treaties are quasi-constitutional in character. They seem to provide, in other words, a subtle or underlying mode of justification, or validation, for governmental claims to authority and legitimacy in international law. ${ }^{17}$ It may be argued, after all, that, in the absence of a general theory of representation in international law, ${ }^{18}$ it is only through its commitment to certain basic human rights standards that international law may be rescued from simply being the law of tyrants, slavers or pirates.

Each of these two understandings, however, works against the other: human rights treaties cannot simply be 'constitutional' insofar as they are constructed in the form of agreements between states (they do not in that sense precede those agreements, and exist only in relation to them). Third parties remain third parties, and states are bound only to the extent that they have formally registered their consent. By the same token, human rights treaties cannot simply be 'ordinary treaties', as they seem to be premised upon the idea that the rights pre-exist not only the treaties themselves, ${ }^{19}$ but also explain or justify the competence of governments in relation to them. We seem to be faced, then, with a problem of semantics when we speak about this species of 'human rights treaties': are we, at any moment, referring to the fact that they are treaties, or to the fact that they instantiate human rights? ${ }^{20}$

17 For an explicit defence of this idea, see, e.g., F. Teson, A Philosophy of International Law (1998). In brief, Teson argues in favour of a 'Kantian' approach to international law which he understands as entailing, among other things, that 'observance of human rights is a primary requirement to join the community of civilized nations under international law' (at 7).

18 Allott complains that 'the consciousness-controlling activities of government ... ensured that sovereignty would be externalized into a society which was conceived as being a society containing only sovereigns, a society which would contain no theory of representation, which would leave obscure and unexplained the sense in which the people of the world might be virtually present in international society by reason of the participation of the state-societies'. P. Allott, Eunomia: New Order for a New World (1990) 303.

f. also Crawford, 'Democracy and International Law', 64 BYbIL (1993) 113.

19 Human rights treaties characteristically speak of the 'recognition' of rights with the implication that those rights have some prior existence. This idea is made more explicit in the preamble to the International Covenant on Civil and Political Rights (1966) which declares, for example, that 'these rights derive from the inherent dignity of the human person'.

20 This conflict is one that not only infects how we think of them as treaties, but also how we think of the human rights contained within them. Is, for example, a violation of an individual right to be determined by the extent to which it offends a naturalistic notion of 'human dignity', or by non-compliance with specifically defined legal obligations? Are we, in other words, able to speak about hunger or poverty as a violation of human rights per se, or only to the extent that it is linked to a failure to comply with specific conventional obligations? A similar disjunction between rights and obligations is apparent in cases where state obligations appear to exceed the 'naturalistic' content of the right concerned, e.g. in cases of reparation for violation of the right to life. 


\section{The Vienna Convention on the Law of Treaties}

The diffidence of general international law as regards the 'speciality' of human rights treaties is well reflected in the terms of the Vienna Convention on the Law of Treaties. The Convention self-consciously attempts to enunciate principles of treaty law that are applicable to all types of treaty (whether they be bilateral, multilateral, law-making, contractual, dispositive or constitutive) and is concerned primarily with the instrument in which obligation is expressed, rather than with the content of those obligations. ${ }^{21}$ It does not, therefore, differentiate in any explicit way between groups of treaties by reference to their subject matter (such as environmental law treaties, treaties of peace, commercial or trade treaties or treaties establishing boundaries or other territorial regimes), nor is any special mention made of the application of treaties to individuals. ${ }^{22}$ Instead, 'flexibility' is built into the regime by means of liberal use of the qualification that the principles be applied by reference to 'the object and purpose' of the treaty concerned. In the case of Article 41(1)(b)(ii) concerning the mutual modification of multilateral treaties, or Article 58(1)(b)(ii) concerning the mutual suspension of such treaties, reference to the object and purpose of the treaties seems to be essential. In neither of these cases would it make much sense for two states to agree that they may suspend or modify a human rights treaty (apart from any other form of treaty) in their relations inter se, as the general standards of treatment would still pertain with respect to all other states. Mutual modification or suspension, in other words, would essentially be ineffective unless, and to the extent that, all other states parties were in agreement.

The one clear exception identified within the Vienna Convention regime seems to be Article 60(5) which provides that provisions relating to suspension following material breach 'do not apply to provisions relating to the protection of the human person contained in treaties of a humanitarian character'. ${ }^{23}$ In practical terms, the rationale for this provision is undoubtedly clear: it would be entirely inappropriate to allow states parties to suspend the operation of a human rights treaty simply because one of their number has materially breached its terms. But whether this is because states would not have any specific legal interest in the default, or for some other reason (such as individuals being the innocent victims of the illegal act, ${ }^{24}$ or because the interests of the international community are involved ${ }^{25}$ ) is less clear.

The one issue that has been recognized as causing problems in the context of treaty

21 Cf. S. Rosenne, Breach of Treaty (1985) 4.

22 See, e.g., Draft Article 66, Waldock, 'Third Report on the Law of Treaties', Yearbook of the International Law Commission, vol. II (1964) 57. See generally Schwelb, 'The Law of Treaties and Human Rights', in M. Reisman and B. Weston (eds), Towards World Order and Human Dignity (1976) 263, at 266-272.

23 See also Legal Consequences for States of the Continued Presence of South Africa in Namibia (South West Africa) Notwithstanding Security Council 276 (1970), Advisory Opinion, ICJ Reports (1971) 16, para. 101. See generally Schwelb, supra note 22, at 274-283.

24 Sir H. Waldock, Yearbook of the International Law Commission, vol. I (1966) 63, para. 23.

25 Ibid, at para. 68. 
law is the question of reservations. ${ }^{26}$ This is a matter that has occupied the International Law Commission for several years ${ }^{27}$ and was the subject of an exchange of views between the Human Rights Committee on the one hand ${ }^{28}$ and several states including the US, France, the UK and Germany on the other. ${ }^{29}$ The full details of this debate are beyond the scope of the present paper, but the central problem is certainly of relevance. Article 20 of the Convention takes the view that there is no automatic requirement of unanimity as to the legitimacy of reservations and, in that regard, follows the position adopted by the ICJ in the Reservations Case. ${ }^{30}$ Rather, it provides that 'an act expressing a State's consent to be bound by the treaty and containing a reservation, is effective as soon as at least one other contracting State has accepted the reservation'. ${ }^{31}$ It states further that the acceptance of a reservation by another state 'constitutes the reserving State a party to the treaty in relation to that other State'; ${ }^{32}$ and that an objecting state may preclude, by express dissent, the entry into force of the treaty as between the objecting and the reserving state. ${ }^{33}$ Leaving aside the question whether this scheme governs all reservations, or simply those that are contrary to the object and purpose of the treaty, ${ }^{34}$ the picture this paints is one in which a state may be regarded as being party to a treaty in relation to some, but not necessarily all other, states parties. It also suggests that, where a state objects to a reservation, but is prepared to accept the reserving state as party to the treaty, the content of those

26 See, e.g., Higgins, 'Human Rights: Some Questions of Integrity', 52 MLR (1989) 1; Redgewell, 'Reservations to Treaties and Human Rights Committee General Comment No. 24 (52)', 46 ICLQ (1997) 390; Shelton, 'State Practice on Reservations to Human Rights Treaties', 1 Canadian Human Rights Yearbook (1983) 205; Coccia, 'Reservations to Multilateral Treaties on Human Rights', 15 California Western International Law Journal (1985) 1; L. Lijnzaad, Reservations to UN Human Rights Treaties: Ratify and Ruin? (1995).

27 See, e.g., Reports of Special Rapporteur Pellet, UN Docs A/CN.4/470, and Corr.1 (1995); A/CN.4/477 and Add.1 (1996); and A/CN.4/491 and Corr.1 (1998).

28 General Comment No. 24 (52), supra note 12.

29 Supra note 16

30 Reservations to the Convention on the Prevention and Punishment of the Crime of Genocide, ICJ Reports (1951), at 23. The main distinction, however, is that the Vienna Convention regime gives states opposing a reservation the choice as to whether or not they wish to be regarded as bound in relation to the reserving state.

31 Article 20(4)(c).

32 Article 20(4)(a).

33 Article 20(4)(b).

34 This turns upon the perceived relationship between Articles 19 and 20 of the Vienna Convention and whether a single-stage or a two-stage test is to be employed. For the view that the latter is to be preferred, see Redgewell, supra note 26, at 404-405; Redgewell, 'Universality or Integrity? Some Reflections on Reservations to General Multilateral Treaties', 64 BYbIL (1993) 245, at 257; and Bowett, 'Reservations to Non-Restricted Multilateral Treaties', 48 BYbIL (1976-1977) 67. The two-stage test, while sound in theory, rests on the assumption that the compatibility of a reservation with the object and purpose of a treaty may be determined without any necessary input from states. The ILC, by contrast, had taken a more realistic view in stating in its commentary that Articles 16 and 17 (later 19 and 20) were to be read together 'because the legal effect of a reservation, when formulated, is dependent on its acceptance or rejection by the other States concerned'. Documents of the Conference, A/CONF.39/11/Add.2, at 23. 
obligations may differ as regards different states parties. ${ }^{35}$ This situation might be suitable in the context of a treaty providing, for example, for a specific tariff regime to be put in place, and in which one is able to distinguish clearly between obligations owed as regards one party, and those owed as regards another. But it makes remarkably little sense in the context of human rights treaties where, by and large, the content or extent of obligations does not vary according to which states are, or are not, party to the treaty, or indeed as to how many states are party. ${ }^{36}$

It may well be objected that the reservations regime, however incompatible in theory, is nonetheless a practical solution to the problem. Special Rapporteur Pellet, in his Second Report on Reservations to Treaties in 1994, takes exactly this position. ${ }^{37}$ The regime of reservations, he asserts, is sufficiently flexible as to effectively cater for all forms of treaties, including, in that regard, human rights treaties, which themselves still seem to contain 'typically contractual clauses'. ${ }^{38}$ There is a certain force to this argument. After all, even if a state is bound only with respect to some of the states parties, this will not affect the substance of the obligations assumed which are owed primarily to individuals within the jurisdiction and control of that state. It matters little, therefore, whether a state is party in relation to all other states parties, or simply just one.

This argument, however, only goes halfway: it deals well enough with the position of the reserving state, but does little to ensure the integrity of the treaty concerned. ${ }^{39}$ To begin with, it would seem that the whole regime is premised upon the belief that the only relevant legal interests in question are those of the participating states, and that those interests may be effectively protected by either preventing the entry into force of the treaty as between the parties, or by the non-application of the provision to which the reservation applies. ${ }^{40}$ If it is accepted, however, that states do not have an individual interest in the achievement of the purposes of the regime but only a common or collective interest (as the ICJ in the Reservations Case suggested ${ }^{41}$ ), it is doubtful whether that interest may be sufficiently preserved where the process is entirely taken up in the actions of individual states. Indeed, since the 'sanctioning effect' of

35 This turns upon the question of severability. Cf. Belilos v. Switzerland, Series A, No. 132. See, Marks, 'Reservations Unhinged: The Belilos Case Before the European Court of Human Rights', 39 ICLQ (1990) 300 .

36 As Simma points out: 'In [the] case of human rights conventions, however, there is simply no contractual quid pro quo to withhold. There is, sociologically speaking, no interaction between the parties onto which reciprocity could lock. Reciprocal non-application of a reserved provision by another State Party would not only be absurd but also legally inadmissible... [S]ince every State Party is bound vis-à-vis every other State Party to perform the treaty obligations, a splitting up of such a treaty into pairs of bilateral contractual relations in respect of which the reciprocal alternation of the treaty standard envisaged by the Convention could operate, is impossible.' Simma, 'International Human Rights and General International Law: A Comparative Analysis', 4 Collected Courses of the Academy of European Law (1995) 153 , at $181-182$.

37 A/CN.4/477/Add.1 (1996).

38 Ibid.

39 Cf. Higgins, 'The United Nations: Still a Force for Peace', 52 MLR (1989) 12.

40 Article 21(3).

41 See the text accompanying note 86 below. 
opposability has little salience in the context of human rights treaties, this individualization of the process of objection will ensure that the effectiveness of a putatively impermissible reservation remains virtually unassailable unless all other states parties both object and specifically refuse to accept the reserving state as a party to the treaty. ${ }^{42}$

\section{The Characteristics of Human Rights Treaties}

In light of this apparent disjunction between the terms of general treaty law and the specific characteristics, or demands, of human rights treaties, it may be thought that we are, in reality, dealing with an issue that cannot simply be treated as a question of 'fine tuning' in the way that the ILC is dealing with the matter. Much as the ILC has wished to maintain the 'integrity' of general treaty law, it does seem that the overriding 'contractual' paradigm is largely (if not wholly) inappropriate in the case of human rights treaties. The extent to which that is true, however, depends first of all upon how the apparent 'peculiarity' of human rights treaties is expressed and understood, and what conclusions are to be drawn from it. There are, of course, a number of possibilities.

First, and most obviously, one might make the point that human rights treaties have, as their humanitarian ideal, the protection of the interests of individuals. This, however, is not sufficiently explanatory insofar as it casts the net rather too widely. Numerous treaties can be said to have such an objective including, not merely those treaties commonly regarded as 'human rights treaties', but also treaties such as the ILO conventions on labour rights, ${ }^{43}$ 'humanitarian treaties' (the Geneva Conventions $^{44}$ and Protocols ${ }^{45}$ and the Hague Regulations ${ }^{46}$ ), and treaties concerned with diplomatic or consular protection, ${ }^{47}$ to name but a few. It is undoubtedly possible that

42 The problem is further exacerbated when the role of supervisory institutions is taken into account. As the Human Rights Committee pointed out in its General Comment No. 24 (52), supra note 12, para. 1: 'It is important for States parties to know exactly what obligations they, and other States parties, have in fact undertaken. And the Committee, in the performance of its duties under either article 40 of the Covenant or under the Optional Protocols, must know whether a State is bound by a particular obligation or to what extent.' If a large number of states object to a reservation on the basis that they believe it to be incompatible with the object and purpose of the treaty, whether or not they wish the reserving state to be a party to the agreement inter se, the supervisory body will necessarily have to take a view on the question of the effect of that reservation. It is clear, irrespective of the precise legal competence of the supervisory body concerned, that leaving the determination of compatibility solely in the hands of states parties acting in an individual capacity, does little to clarify that process.

43 E.g., ILO Convention (No. 87) Concerning Freedom of Association and Protection of the Right to Organize (1948); ILO Convention (No. 98) Concerning the Application of the Principles of the Right to Organize and to Bargain Collectively (1949); and ILO Convention (No. 122) Concerning Employment Policy (1964).

44 Geneva Conventions I to IV (1949).

45 Protocol I Concerning the Protection of Victims of International Armed Conflicts (1977); Protocol II Concerning the Protection of Victims of Non-International Armed Conflicts (1977).

46 Hague Regulations of 1899 and 1907.

47 E.g., Vienna Convention on Consular Relations (1963). See Case Concerning Consular Rights of Detained Foreign Nationals, Inter-American Court of Human Rights, Advisory Opinion, OC-16/99. 
the category of 'human rights' treaties may be larger or smaller than specific designation might lead to suppose, but it is also apparent that in widening the scope, one is less able to construct an argument for special treatment. The same may be said of the argument that the peculiarity of human rights treaties is found in the fact that they provide for the recognition of individual legal 'rights'. Once again, it is clear that individual 'rights' — and more specifically 'rights of petition' — are recognized in a much wider range of treaties than simply those concerned strictly with 'human rights' (including, for example, Article 87(b) of the UN Charter, and Article 304 of the Peace Treaty of Versailles). Unless arguments as to the specificity of 'human rights treaties' as a category are entirely ill-conceived, it seems clear that neither of these characteristics alone sufficiently explains why 'human rights treaties', in particular, have been regarded as being of a special nature.

Those bodies that have come to recognize the specific characteristics of human rights treaties (included here are the International Court of Justice, the European Commission and Court of Human Rights, the Inter-American Court of Human Rights and the Human Rights Committee) have almost unanimously locked onto a single question: that of 'reciprocity' (or, more specifically, the lack of it). ${ }^{48}$ The best, but not necessarily the most well-known, expression of this idea was that provided by the Inter-American Court of Human Rights in the Effect of Reservations Case:

modern human rights treaties in general, and the American Convention in particular, are not multilateral treaties of the traditional type concluded to accomplish the reciprocal exchange of rights for the mutual benefit of the contracting States. Their object and purpose is the protection of the basic rights of individual human beings irrespective of their nationality, both against the State of their nationality and all other contracting States. In concluding these human rights treaties, the States can be deemed to submit themselves to a legal order within which they, for the common good, assume various obligations, not in relation to other States, but towards all individuals within their jurisdiction. ${ }^{49}$

It would be fair to say that the main point which stimulated the Court's approach in this regard was to contrast the Convention regime on the one hand with the standard principles governing diplomatic protection on the other. Whilst the principles of diplomatic protection are premised upon the idea that in seeking to protect its own nationals from the actions of third states, a state is in fact asserting its own rights, ${ }^{50}$ the Inter-American Convention regime was quite different. Not only did it dispose of the relevance of nationality for the purpose of protection, but it was no longer concerned

48 General Comment No. 24 of the Human Rights Committee notes, for example, that human rights treaties 'are not a web of inter-state exchanges of mutual obligations. They concern the endowment of individuals with rights. The principle of inter-state reciprocity has no place save perhaps in the limited context of reservations to declarations on the Committee's competence under Article 41.' General Comment No. 24 (52), supra note 12, para. 17. See generally A. Cançado Trinidade, A Protecao International dos Direitos Humanos — Fundamentos Juridicos e Instrumentos Basicos (1991) 10-12.

49 The Effect of Reservations on the Entry into Force of the American Convention on Human Rights (Arts 74 and 75), Advisory Opinion OC-2/82 of 24 September 1982, Inter-American Court of Human Rights (1982), Series A, No. 2, para. 30.

50 Mavrommatis Palestine Concessions Case (Jurisdiction), 1924 PCIJ Series A, No. 2, at 12. 
exclusively with the 'rights of states'. This issue of non-reciprocity, therefore, seems to be the key to unlocking the puzzle of human rights treaties.

Even if the 'peculiarity' of human rights treaties is found in the idea of non-reciprocity, it is immediately apparent that many treaties that putatively fall within this category do not bear that characteristic. Certain treaties, such as the European Social Charter of $1963^{51}$ and the Migrant Workers Convention, specifically premise the enjoyment of certain rights on the possession of nationality of one of the states parties and therefore reinforce the importance of reciprocity. In such cases, the question whether an individual is to enjoy a particular right is contingent upon the state of nationality becoming party to the treaty and therefore the rights of individuals are barely distinguishable from the rights of states. The same can be said for 'humanitarian' treaties — such as the Geneva Conventions of 1949 or their Additional Protocols - which are again premised upon a mutual acceptance of obligations on the part of the states concerned..$^{52}$ It would seem then, in speaking about non-reciprocal human rights regimes, we are speaking about a limited category of treaties whose purpose is to recognize and protect individual human rights in a way that is independent of the question of nationality, or of the acceptance of similar obligations by any other particular state party. Treaties that fall within this category presumptively include, among others, the International Covenant on Civil and Political Rights (1966), ${ }^{53}$ the International Covenant on Economic, Social and Cultural Rights (1966), ${ }^{54}$ the International Convention on the Rights of the Child (1989), ${ }^{55}$ the International Convention on the Elimination of All Forms of Racial Discrimination (1965), ${ }^{56}$ the Convention on the Elimination of All Forms of Discrimination Against Women (1979), ${ }^{57}$ the Convention Against Torture and Other Cruel, Inhuman or Degrading Treatment or Punishment (1984), ${ }^{58}$ the European Convention on Human Rights and Fundamental Freedoms (1950) $)^{59}$ and the Inter-American Convention on Human Rights (1969). ${ }^{60}$ Each of these treaties has its own special characteristics, but they do possess sufficient commonality in terms of structure and form to be treated as a relatively discrete category.

\footnotetext{
51529 UNTS 89.

52 Common Article 2 of the Geneva Conventions (1949) provides that: 'Although one of the Powers in conflict may not be a party to the present Convention, the Powers who are parties thereto shall remain bound by it in their mutual relations. They shall furthermore be bound by the Convention in relation to said Power, if the latter accepts and applies the provisions thereof.'

53999 UNTS 171.

54993 UNTS 3.

5528 ILM (1989) 1456.

$56 \quad 660$ UNTS 195.

5719 ILM (1979) 33.

5824 ILM (1985) 535.

59213 UNTS 221.

609 ILM (1981) 59.
} 


\section{The Concept of the Treaty: Consent and Reciprocity}

It has to be said that the idea of a non-reciprocal 'treaty' does appear, on the face of it, to be a contradiction in terms. In their simplest form, treaties are conceived primarily in terms of an analogy with contracts in municipal law ${ }^{61}$ - that is, as consensual arrangements instituting, through the medium of legal rights and duties, a reciprocal exchange of goods or benefits. ${ }^{62}$ If that is the case the claim to non-reciprocity on the part of certain human rights treaties suggests that they are either an entirely novel form of treaty, or perhaps not treaties at all. Such a conclusion, however, is dependent upon the extent to which reciprocity is understood as a critical element of treaty law, and upon how that reciprocity is conceptualized.

If one turns to the Vienna Convention on the Law of Treaties for advice, there is no obvious answer as to the role or importance of reciprocity. The Convention simply defines a treaty (in Article 2) as 'an international agreement concluded between states in written form and governed by international law'. Although one may read much into the idea of an 'agreement', ${ }^{63}$ no explicit mention is made either of the notion of reciprocity or that of 'consent' which might otherwise be thought to underlie the idea of a 'treaty'. A reading of the later Articles of the Vienna Convention, however, suggests that both such elements are indeed central to the definition.

First of all, there seems to be no doubt that, according to the Convention, the 'agreement' is constituted in a mutual expression of consent. Articles 11-14 define the means by which the consent of a state to be bound by a treaty may be expressed and 'consent' is deemed central to the putative invalidity of the treaty (Articles 48-51), its termination (Article 54), and for the assumption of rights and obligations on the part of third states (Article 34). What is critical, however, is not simply that that consent is expressed, but that it is expressed in a context of 'mutuality': that, in other words, it takes on a synallagmatic form. Even if one accepts that unilateral declarations may create legally binding obligations (whether or not erga omnes), ${ }^{64}$ it is clear that the idea of an 'agreement' within the terms of the Convention is not constituted in the acts of individual states. If otherwise, the idea of 'third states' would be literally impossible to conceive, and the notion of mutual modification rendered

61 See generally H. Lauterpacht, Private Law Sources and Analogies of International Law (1927) 155-180; and J. Brierly, The Law of Nations (6th ed., 1963) 317-327. R. Jennings and A. Watts, Oppenheim's International Law, vol. I (8th ed.) 877, defines treaties as 'agreements, of a contractual character, between States, or organizations of States, creating legal rights and obligations between the parties'.

62 Bernhardt defines a treaty as 'a consensual agreement between two or more subjects of international law intended to be and considered by the parties as binding and containing rules of conduct under international law for at least one (normally for all) of the parties'. Bernhardt, 'Treaties', in R. Bernhardt (ed.), Encyclopedia of Public International Law, vol. VII (1984) 459, at 460.

63 An 'agreement' would naturally appear to represent a concurrence of opinion or belief as between two or more persons in relation to some fact or course of action.

64 See, e.g., Nuclear Tests Case (Australia v. France; New Zealand v. France), ICJ Reports (1974), at 253; Military and Paramilitary Activities in and against Nicaragua, ICJ Reports (1986), at 131, para. 259; Frontier Dispute Case, ICJ Reports (1986) 554, at 573; and Border and Transborder Armed Actions Case, ICJ Reports (1988) 105-106, para. 94. See generally Franck, 69 AJIL (1975) 612; Rubin, 'The International Legal Effects of Unilateral Declarations', 71 AJIL (1977) 1; Macdonald and Hough, 'The Nuclear Tests Case Revisited', 20 German Yearbook of International Law (1977) 337. 
meaningless. In this context, the principle pacta sunt servanda must mean not just that 'promises shall be kept', 65 as is so often assumed, but more specifically and literally that 'agreements shall be followed'. It is, in other words, the multi-party, or relational, dimension of a pactum that is central to the assumption of obligations in treaty law.

If treaties can only really be understood as 'agreements' between mutually consenting parties, it does not necessarily follow that they are to be regarded as 'reciprocal'. ${ }^{66}$ Indeed, it is apparent that as explanatory mediums the concepts of reciprocity and consent do not necessarily pull in the same direction. As Sandel has pointed out, the morality of any contract or agreement can be understood by reference to 'two related yet distinguishable ideals': one being the ideal of autonomy, which understands its morality in terms of the voluntary character of the transaction, the other being the ideal of reciprocity which understands its morality as being dependent upon the underlying fairness of the exchange. ${ }^{67}$ Sandel argues that:

Each ideal suggests a different basis for contractual obligation. From the standpoint of autonomy, a contract's moral force derives from the fact of its voluntary agreement ... The ideal of reciprocity, on the other hand, derives contractual obligation from the mutual benefits of cooperative arrangements. Where autonomy points to the contract itself as the source of obligation, reciprocity points through the contract to an antecedent moral requirement to abide by fair arrangements, and thus implies an independent moral principle by which the fairness of an exchange may be assessed. ${ }^{68}$

Whilst theoretically distinct, each account of obligation exposes the incompleteness of the other: an emphasis on consent will potentially lead to one being bound by terms that are unfair; and an emphasis on reciprocity will potentially lead to one being bound in ways that one did not choose. Consent, therefore, may on occasion be used as an argument to counter a claim to lack of reciprocity; and reciprocity (fairness) may, on occasion, be used as an argument to counter a claim to a lack of consent. Consent and reciprocity are not, in that sense, mutually reinforcing, and indeed may supplant one another for the purposes of determining the presence of obligation in particular circumstances.

Returning to the Vienna Convention, then, it would appear that the predominance of mutual consent in the construction of a valid treaty necessitates the marginalization of 'material' reciprocity as a condition sine qua non. Indeed, it is clear that

65 Thirlway comments, in relation to the Nuclear Tests Case, that: "The rule of pacta sunt servanda is based on a very fundamental idea or principle, and it may be that that fundamental idea can justify attaching legally binding effect to something which, lacking two-sidedness, is not a pactum; but "good faith" is perhaps not the best name for it.' Thirlway, 'The Law and Procedure of the International Court of Justice 1960-1989, Part One', 60 BYIL (1989) 1, at 9.

${ }^{66}$ It should be noted that there is a difference between two states simply owing obligations to one another within the framework of a legal instrument and those obligations taking on a form of reciprocity that makes the effect of one conditional upon performance of the other.

67 Schwarzenberger argues, however, that reliance upon reciprocity merely gives a legal system the appearance of being grounded in justice whilst obscuring the powers behind and within the system: Schwarzenberger, 'Jus Pacis ac Belli? Prolegomena to a Sociology of International Law', 37 AJIL (1943) 460 , at 478 .

68 Sandel, Liberalism and the Limits of Justice (1982) 106. See generally C. Fried, Contract as Promise (1981); and P. Atiyah, The Rise and Fall of Freedom of Contract (1979). 
the Convention does not invoke any concept of 'consideration' or 'cause' for the purpose of determining the obligatory effect of treaties. Such an understanding is reflected in general doctrine: it is possible, after all, to conceive of treaties in which one state simply agrees to do something with no substantive or formal quid pro quo. The unconditional cession of territory from one state to another by means of treaty might be a good example, as indeed may be the conclusion of a treaty of peace. In such cases, states will assume an obligation to undertake a certain course of action not in a conditional sense - as being dependent upon the actions or omissions of other states parties - but in the sense of a simple promise made in a context of mutuality. ${ }^{69}$ That being the case, the constituents of an 'agreement', therefore, do not seem to be contingent upon the content of the instrument which may, or may not, provide for a mutual exchange of goods or benefits. Rather, the constituents are simply formal and found in the expression of a concurrent and mutual act of will. It is noticeable, in that respect, that the Vienna Convention makes no mention of the old category of 'unequal treaties' - treaties that are, in one form or another, 'unfair' or which lack real reciprocity - and provides for no 'escape' from obligations by reason of their content alone. ${ }^{70}$ The one exception, here, is of course where the content of the treaty conflicts with a peremptory norm of general international law, ${ }^{71}$ but such cases are regarded as exceptional (the content of jus cogens itself being unclear). By the same token, reciprocity may enter the equation at the point of determining whether breach by one party of an agreement will entitle the other to suspend the agreement, ${ }^{72}$ but that, by definition, is not an issue that goes to the heart of what constitutes a treaty in the first place.

Whilst it may be concluded, therefore, that treaties are not necessarily marked by any form of 'reciprocal exchange' of goods or benefits, the importance placed upon the 'mutuality' of consent suggests that some form of reciprocity might nevertheless be relevant. As we have dealt with the notion thus far, it has been understood in terms of a material exchange of goods or benefits (as, in other words, a form of 'consideration'). Reciprocity, however, can also be understood in other ways. It may, for example, be understood by reference to the political, psychological or sociological interests that underlie the agreement. In this context, it would presumably always be possible to identify mutual interests in the making of a treaty, whether or not the content of the treaty is such as to leave one state in a better position than the other. The importance placed upon consent, after all, assumes that states pursue their interests primarily by means of explicit intentional acts and may, for sundry reasons, accept through consent binding international obligations that restrict their future freedom of action.

69 As the ICJ noted in the South West Africa Case (Second Phase), ICJ Reports (1966) 32: 'a legal right or interest need not necessarily relate to anything material or "tangible", and can be infringed even though no prejudice of a material kind has been suffered.'

70 Treaties procured by the threat or use of force may be regarded as 'unfair', but their effect, according to Article 51 of the Vienna Convention, is to nullify the presence of consent. They are not, therefore, treaties rendered null as a result of coercion, but simply not treaties at all.

71 Article 53 of the Vienna Convention on the Law of Treaties (1969).

72 Ibid, Article 60. 
To say then that states may consent to matters that are not in their own interest (whether in the short, medium or long term) is to say either that they have not properly consented or that they are simply acting irrationally. An emphasis on consent, after all, seems to prioritize a form of purposive rationality, and purposive rationality supposes that treaties are expressive of a mutuality of state interests.

Leaving aside the two understandings of reciprocity outlined above (one concerned with the material fairness of the exchange, the other by the psychological content of 'agreeing') there is a third understanding of reciprocity that corresponds more closely to its ordinary usage in legal doctrine. ${ }^{73}$ As Simma points out, "as a sociological category, motivations prompted by the expectation of reciprocity should clearly be distinguished from reciprocity as an objective aspect of a given legal relationship' ${ }^{74}$ Reciprocity in this third sense represents the logical legal framework of the contract. It is, in that sense, expressive of a mutual, but conditional, exchange of legal obligations in which the possession of rights and obligations of one party are linked to (and perhaps dependent upon) those of the other party. ${ }^{75}$ If a state assumes rights or obligations under the terms of a treaty, it is supposed that it must assume them in relation to another legal person, and that other legal person must be a party to the agreement (as otherwise the pacta tertiis principle would have little salience). This 'legal reciprocity' assumes, in other words, a dyadic or relational framework of rights and obligations that binds contracting parties only and exclusively as regards other contracting parties (leaving aside the possibility that third states may be assigned and assume rights and obligations in certain limited circumstances). ${ }^{76}$

The relational framework set up by this idea of legal reciprocity can be understood most clearly in bilateral terms according to which one party's rights and obligations are directly linked to those of all other states parties ut singuli. It is only by reason of this structure that one is able to speak of the bilateral suspension or modification within the framework of a multilateral treaty, ${ }^{77}$ and to the acceptance of reservations by some, but not all, treaty parties. The logic of reciprocity, however, derives not so much from the nature of treaty relations, per se, but from the apparent imperatives of a decentralized international system. As Simma has noted:

As long as the international legal order lacks a centralized enforcement machinery and thus

73 See, e.g., Simma, who points out that ' $[\mathrm{t}]$ o recognize that in the case of a human rights treaty States parties do not exchange any tangible benefits is one thing. But then to assert that such absence of factual, or "sociological" reciprocity, as it were, leads to the absence of reciprocal legal rights and duties proper is quite another matter. By no means is the second claim a necessary conclusion from the first.' Simma, 'From Bilateralism to Community Interest', Hague Recueil (1994) 369.

74 Simma, 'Reciprocity', in R. Bernhardt (ed.), Encyclopedia of Public International Law, vol. 7 (1984) 400.

75 Cf. Ago, who makes the more extensive claim that there was always 'a correlation between a legal obligation, on the one hand, and a subjective right, on the other': Ago, Second Report, Yearbook of the International Law Commission, vol. II (1970) 192.

76 Simma, supra note 73, at 400-401, states that: 'From a purely formal point of view, reciprocity governs every international agreement, independently of its content, and consequently underlies the rules concerning the conclusion and entry into force of treaties, and their application, termination, amendment and modification.'

77 See, e.g., Article 58 of the Vienna Convention on the Law of Treaties (1969). 
has to live with autodetermination and self-help, reciprocity will remain the principle leitmotiv, a constructive, mitigating and stabilizing force, the importance of which can hardly be overestimated. $^{78}$

It is only by reason of reciprocity, therefore, that states will be able to participate in international relations without exposing themselves unduly to the risks involved with non-compliance on the part of other states: ${ }^{79}$ it provides the means, in other words, by which states may effectively 'police' those obligations by means of self-help.

In light of the evident importance of reciprocity within general international law, to suggest that certain treaty relations exist which are not premised upon reciprocity appears not only to be a denial of the pertinence of general treaty rules, but also a signal exception to the working suppositions of international law. It would, in particular, be suggestive either of the idea that international law has begun to develop beyond the confines of its own anarchical premises, ${ }^{80}$ or that the development of specific regimes has occurred in a partially independent way. In either case, the consequences are significant for the way in which international law as a whole is understood.

\section{Reciprocity in the Context of Human Rights Treaties}

As has been suggested thus far, the issue of reciprocity seems to present a particular problem when examining the category of human rights treaties. On the one hand, we are presented with a recurrent claim that principles of treaty law should be modified or set aside by reference to the putative non-reciprocal character of human rights treaties, whilst, on the other, we are faced with the idea that legal reciprocity is in reality a constitutive element of treaty relations (or at least the dominant paradigm for those relations). If some sense is to be made of this, therefore, it would seem that there is a need to strategically revisit some of the landmark cases in which the argument as to non-reciprocity began to emerge.

The first, and certainly most influential, case dealing with the application and effect of reservations to 'humanitarian' treaties was the ICJ's Advisory Opinion in the Reservations Case of $1951 .{ }^{81}$ In that case, the Court placed considerable emphasis upon what it saw to be the 'special nature' of the Genocide Convention:

78 Simma, supra note 73, at 400. And further: 'As a horizontal legal system, international law rests upon the logic of reciprocity in its entirety. Reciprocity is at work not only behind the long-established 'traffic rules' of routine international relations but also with equal force behind the legal attempts both to curtail the extremes of power politics and to organize international cooperation for human welfare, irrespective of the political and ideological antagonisms that divide the contemporary world.'

79 As it is put in The Christina [1938] AC 485: 'each ... State within the community of nations accepting some subtraction from its full sovereignty in return for similar concessions on the side of others.'

80 For the view that 'reciprocity' marks out a transitional phase in the development of a legal order (from bilateral- to system-level analysis), see E. Decaux, La Reciprocite en droit international (1980) 9.

81 Reservations to the Convention on the Prevention and Punishment of the Crime of Genocide, ICJ Reports (1951) 23. 
In such a Convention the contracting States do not have any interests of their own; they merely have, one and all, a common interest, namely, the accomplishment of those high purposes which are the raison d'etre of the convention. Consequently in a convention of this type one cannot speak of individual advantages or disadvantages to States, or of the maintenance of a perfect contractual balance between rights and duties. ${ }^{82}$

In the circumstances, therefore, the Court was led to modify the general rule of unanimity as regards the permissibility of reservations ${ }^{83}$ and substitute, in its place, a rule that allowed states to be considered party to the Convention even in cases where another state may have objected to a reservation. ${ }^{84}$ The precise rationale for this was, apparently, that:

The object and purpose of the Genocide Convention imply that it was the intention of the General Assembly and of States which adopted it that as many States as possible should participate. The complete exclusion from the Convention of one or more States would not only restrict the scope of its application, but would detract from the authority of the moral and humanitarian principles which are its basis. ${ }^{85}$

What is immediately apparent from the extracts quoted above is that the implications of the first statement are not entirely borne out in the solution proposed by the Court. If it is to be said that 'one cannot speak of individual advantages or disadvantages', or of the maintenance of a 'perfect contractual balance' in the context of the Genocide Convention, it may seem surprising that a state could be considered party to the treaty in relation to some, but not all, states parties. Surely, if the interest is of a 'common' or 'collective' nature, then the question whether a state is, or is not, a party to the treaty should be for the 'collective' to determine (and not states ut singuli). The logical response may be that in employing the characteristic liberal methodology of international law, the only means of determining the content of the 'collective interest' is to seek the views of individual states parties and build up a probabilistic picture from their response. But even then it is hard to justify why one or two objecting states should be able to determine their own position in circumstances in which there is a general presumption that the reserving state should indeed be regarded as a party to the treaty. The 'contractual balance', therefore, seems to have been reintroduced

82 Ibid.

83 The League of Nations took the view that the validity of a reservation depended upon acceptance by all contracting parties. See, e.g., 'Report of League of Nations Committee of Experts for the Progressive Codification of International Law', 8 LNOJ (1927) 880, at 881.

84 The Court suggested that the following principles should apply (at 15): 'that a State which has made and maintained a reservation which has been objected to by one or more of the parties to the Convention but not by others, can be regarded as being a party to the Convention if the reservation is compatible with the object and purpose of the Convention; otherwise that State cannot be regarded as being a party to the Convention. [T] hat if a party to the Convention objects to a reservation which it considers to be incompatible with the object and purpose of the Convention, it can in fact consider that the reserving State is not a party to the Convention. [T] hat if, on the other hand, a party accepts the reservation as being compatible with the object and purpose of the Convention, it can in fact consider that the reserving State is a party to the Convention.' The origins of the principles established by the Court are to be found in the policy adopted by the Pan-American Union in 1932, see Reservations to Multilateral Conventions, UN Doc. A/1372, 11.

85 Ibid. 
into the equation as a result of a palpable lack of epistemic access to 'collective interests' when utilizing a methodology that begins and ends with individual states. ${ }^{86}$

The solution proposed by the ICJ in the Reservations Case and, indeed, that assumed later by the ILC in drafting Article 20 of the Vienna Convention, clearly does not sit very easily with its description of the special characteristics of the Genocide Convention itself. In fact, there is a case for saying that the first passage (concerning the absence of 'individual State interests') is largely redundant. After all, the argument that unanimity is no longer a prerequisite for determining the validity of a reservation could simply be achieved by recognizing that the 'object and purpose of the treaty' spoke in favour of universal participation, and that in turn dictated a presumption of conformity. This is not assisted in any material way by denying the fact of reciprocity or indeed by identifying the existence of a 'common' or 'collective' rather than an 'individual interest'. It is simply a particular construction given to the fact of silence.

In light of these points, an alternative explanation for the position of the Court in this case seems to be necessary. The best explanation, in fact, seems to draw less upon the 'special' characteristics of the Genocide Convention and more upon the mechanisms for enforcement found within it. Unlike the other human rights treaties referred to above, the Genocide Convention does not envisage enforcement (or supervision) by means of a dedicated institution. Rather, Article IX of the Genocide Convention explicitly provides that:

Disputes between the Contracting Parties relating to the interpretation, application or fulfilment of the present Convention, including those relating to the responsibility of a State for genocide ... shall be submitted to the International Court of Justice at the request of any parties to the dispute.

Since the Convention specifically lays down procedures for 'dispute resolution' (using that idea in its proper sense), and since it is in respect of Article IX that reservations are most frequently attached, ${ }^{87}$ it does indeed make sense to suggest that two states may be regarded as parties to the Convention, but not necessarily parties inter se. All that would follow from this is that the states parties concerned would not be able to rely upon the Genocide Convention in order to found the jurisdiction of the

86 The consequential relativism inherent in this position is not merely accidental. In fact, it is expressive of the classic paradox of an individualist methodology that infects much of international law: without any authoritative means of determining who is right, we must either assume that everyone is (relativism), or that no one is (scepticism). Since 'law', in a sense, demands an answer, relativism appears the only option. But, as with all relativist positions, the formulation contains a fatal flaw, namely, that we assume that the quality of being 'right' is more than simply an individual preference and that it is tied, in some significant respect, to the views of the relevant community (an 'epistemic community' perhaps). Unfortunately, however, within the framework of a liberal methodology, the voice of that community will virtually always remain inaudible, and we can but only assume that it exists.

87 Reservations to Article IX have been made by Albania, Algeria, Argentina, Bahrain, Bangladesh, China, India, Malaysia, Morocco, the Philippines, Rwanda, Singapore, Spain, the USA, Venezuela, Vietnam and Yemen. 
ICJ in case of dispute. ${ }^{88}$ If this is the explanation, however, it is explicitly premised upon some idea of reciprocity, at least in the context of dispute resolution.

It would seem, then, that if the issue of non-reciprocity does have salience in relation to 'human rights' or 'humanitarian' treaties, it is not in the manner laid down by the ICJ in the Reservations Case, nor is it best demonstrated by a treaty whose only form of 'supervision' is that rendered by the ICJ. ${ }^{89}$ The case is of importance, however, insofar as it highlights two further questions that need to be addressed: first, if the logic of non-reciprocity is taken at face value, what would this suggest for the question of reservations? And, secondly, to what extent do provisions for 'dispute resolution', ${ }^{90}$ and more generally for international supervision and enforcement, serve to deny this pretension of non-reciprocity? Those two issues have themselves been the subject of further deliberation in the context of regional human rights treaties, and the answers provided have been startlingly different from that proposed by the ICJ.

\section{A Non-Reciprocity and Reservations: The Effect of the Reservations Case}

An answer to the first issue - the issue of reservations - was provided by the Inter-American Court of Human Rights in 1982 when it was called upon to determine the effect of a reservation upon the date of a state's accession to the Inter-American Convention on Human Rights. ${ }^{91}$ The approach of the Court to this issue was far more consistent as regards the logic of non-reciprocity than that of the ICJ. But even here, some of its conclusions may be questioned. The Court, taking its cue from the European Commission ${ }^{92}$ and the ICJ $^{93}$ before it, indicated not only that the treaty did not embody a 'reciprocal exchange of rights for the mutual benefit of the contracting parties', but also that in ratifying the treaty states submitted themselves 'to a legal order within which they, for the common good, assume various obligations, not in

88 As was pointed out by the ICJ in the Case Concerning the Legality of the Use of Force (Yugoslavia v. Canada), 2 June 1999, para. 19: 'the Court has repeatedly stated "that one of the fundamental principles of its Statute is that it cannot decide a dispute between States without the consent of those States to its jurisdiction" (East Timor, Judgment, ICJ Reports (1995) 101, para. 26); and ... the Court can therefore exercise jurisdiction only between States parties to a dispute who not only have access to the Court but also have accepted the jurisdiction of the Court, either in general form or for the individual dispute concerned.' Ironically enough, this would mean that, by objecting to a reservation to Article IX (concerning the jurisdiction of the ICJ), a state would in fact affirm the effectiveness of the reservation.

89 This is particularly important if one is to take seriously the idea that human rights treaties are constitutive of quasi-independent 'legal regimes'. See the text accompanying notes 122-125.

90 A similar provision is found in Article 22 of the International Convention on the Elimination of All Forms of Racial Discrimination (1965). Article 29 of the Convention on the Elimination of All Forms of Discrimination Against Women (1979) and Article 30 of the Convention Against Torture similarly provide for submission of disputes to arbitration.

91 The Effect of Reservations on the Entry into Force of the American Convention (Arts 74 and 75), Advisory Opinion OC-2/82, Inter-American Court of Human Rights (1982), Series A, No. 2.

92 Austria v. Italy (Pfunders Case), 11 January 1961, 4 Yearbook of the European Convention on Human Rights (1961) 116.

93 Reservations to the Convention on the Prevention and Punishment of the Crime of Genocide, ICJ Reports (1951) 23. 
relation to other States, but towards all individuals within their jurisdiction'. ${ }^{94}$ The rights involved, therefore, were the rights of individuals, not of other states, and the framework within which they are protected was one of a 'regime' or 'legal order', and not simply a relation in the nature of a bilateral agreement.

As a result of these considerations, the Court concluded, in contrast to the ICJ before it, that it would be "manifestly unreasonable"95 to suggest that Article 20(4) of the Vienna Convention applied with the effect of conditioning the entry into force of the American Convention for a particular state upon the acceptance of its reservation by other contracting states. ${ }^{96}$ It pointed out that '[a] treaty which attaches such great importance to the protection of the individual ... can hardly be deemed to have intended to delay the treaty's entry into force until at least one other State is prepared to accept the reserving State as a party'. ${ }^{97}$ The presumption must, therefore, be one of the conformity of reservations, and the fact of silence interpreted (perhaps) as tacit consent. $^{98}$

The approach ultimately adopted by the Inter-American Court does seem to be far more consistent with the idea of non-reciprocity in the sense that a state's capacity to partake of the regime is not to be conditioned upon its acceptance by other states parties. It is undoubtedly controversial, however, insofar as it seems to suggest that the act of ratification is in the nature of a unilateral act on the part of each 'contracting' state and that other states, therefore, have no legal interest in the nature or quality of that act. It should be pointed out, furthermore, that in denying the relevance of Article 20(4), the Court also seems to deny the relevance of Article 21 concerning the opposability of a reservation. If a state can become party to the Convention entirely independently of the views of other contracting states, it makes little sense then to suggest that the reservation may be opposable. The underlying idea, of course, is that the regime is a strictly non-relational one (or at least only relational as between states and individuals).

The first obvious drawback to the Court's approach in relation to reservations is that the process of acceptance of, or objection to, reservations has a dual function: it

94 Supra note 91, para. 30.

95 Ibid, at para. 34.

96 Article 20(4)(c) provides that an act expressing a state's consent to be bound by a treaty and containing a reservation 'is effective as soon as at least one other contracting state has accepted the reservation'. Article 20(5) indicates, in addition, that a reservation is automatically considered to have been accepted by a state if it raises no objection by the end of a period of 12 months after notification.

97 Supra note 89 , para. 34.

98 It is evident that, in reaching this conclusion, the Court was not simply extemporizing loosely on the nature of the American Convention but was, in fact, faced with an apparent textual conflict between two different provisions. On the one hand, Article 75 of the Convention provided that ' $\mathrm{t}$ ] his Convention shall be subject to reservations only in conformity with the provisions of the Vienna Convention on the Law of Treaties', whilst, on the other hand, Article 74(2) provided that the Convention should enter into force 'on the date of the deposit of [the] instrument of ratification'. In light of Article 20 of the Vienna Convention - which suggests that acceptance of a reservation by at least one state party is necessary for the reserving state to become party to the treaty - the only way of reconciling the two provisions was by qualifying the sense of one or other provision. That the Court chose to qualify Article 75 and to exclude, thereby, the applicability of Article 20 of the Vienna Convention is nonetheless significant. 
both preserves the rights and interests of other states parties within the contractual arrangement, whilst simultaneously protecting the integrity of that agreement as a whole. In many treaties these two elements are indivisible in the sense that the agreement is wholly constituted by reference to the legal interests of each individual state party. In human rights treaties, by contrast, these two elements are relatively discrete. The point is, however, that in dispensing with the requirement that reservations be accepted or rejected by other contracting states, the permissibility of a reservation may thereby go entirely unchallenged, and, if so, the integrity of the treaty may ultimately be put at risk. This is reinforced by the fact that the jurisdiction of the Court - which might otherwise concern itself with the compatibility of reservations — is based upon consent. ${ }^{99}$ In the absence of a declaration by a reserving state accepting the jurisdiction of the Court, the only body capable of effectively determining the compatibility of a reservation with the object and purpose of the Convention would be the Commission - and the Commission, of course, has no specific competence in relation to the interpretation or application of the Convention. $^{100}$

Much as this drawback is of significance, it should not be overplayed. It is clear, after all, that the 'sanctioning' effect of the Vienna Convention regime itself is barely evident in the case of human rights treaties. If the only consequence of entering a putatively impermissible reservation is that one or two other states refuse to recognize the reserving state as party to the treaty, ${ }^{101}$ there is no reason to suppose that a (non-binding) recommendation of the Inter-American Commission would be of any less significance. Indeed, it would be true to say that the Commission is less likely to be concerned with the political fall-out of declaring a reservation incompatible than would be individual states, and, indeed, is more likely to deal with reservations in a more systematic manner. The formal legal incapacity of the Commission, like that of other human rights bodies (including, here, the Human Rights Committee), should not itself be seen as any great impediment to their ability to express views as to the compatibility of reservations. ${ }^{102}$ After all, it would be entirely open for reserving states to ignore those views, as indeed it would for them to ignore the views of other individual states parties.

The main problem arising from the Court's approach in this case concerns the question of enforcement or supervision. If states have no 'legal interest' in who may

99 Article 62 of the Inter-American Convention on Human Rights (1969).

100 The Inter-American Court has affirmed that 'recommendations' of the Commission do not have 'the character of an obligatory judicial decision for which the failure to comply would generate State responsibility': Caballero Delgado and Santana Case, Inter-American Court of Human Rights, 3 IHRR (1996) 548, 17 HRLJ 24.

101 As is pointed out by Hampson ('Working Paper on Reservations to Human Rights Treaties', UN Doc. E/CN.4/Sub.2/1999/28, para. 10): 'When one considers the number of multilateral treaties to which many States are party and the number of potential other parties, it would be surprising if States were meticulous in examining the reservations of other States in order to indicate a view. Silence seems to be a common response. It would seem unlikely to be usually the result of conscious deliberation on the part of other high contracting parties.'

102 Cf. General Comment No. 24 (52), supra note 12. 
become a party to the Convention, does it follow that they similarly have no direct legal interest in compliance? The underlying issue, of course, is whether the characterization of the Convention as a non-reciprocal, or an 'objective', regime is simply a generalized appraisal of the Convention, or true in all its facets. The standard answer to the question is, on the face of it, relatively simple. Not only does the phraseology of the Convention make clear that implementation is a matter of concern to all states parties, ${ }^{103}$ but, more importantly, Article 45 explicitly provides for an inter-state communication procedure. This would seem to suggest that even if states assume obligations primarily in relation to individuals within their jurisdiction, the performance of those obligations is still a matter of legal concern to other states parties. The fact that Article 45 is an optional procedure does not detract from this argument insofar as Article 45 does not purport to establish the rights and duties of states in their relations inter se, but rather merely delimits the competence of the Commission in relation to those (pre-existent) rights and duties. It would seem, then, that the legal interest that states parties possess in relation to compliance is not simply an indirect one, in the sense of flowing from a concern to ensure that "promises are kept'. If that were the case, there would be no overriding reason why states from other regions, and other non-state parties, should not be competent to submit communications. Rather, it is a more direct legal interest that draws upon the fact that this is a treaty regime embodying, in some form or other, rights and obligations that may lead to the legal engagement of one state party by another. ${ }^{104}$ Ultimately, therefore, it would seem that the critical point around which the discussion of reciprocity turns is that of 'enforcement' and the characteristics of the 'supervisory' regimes instituted within human rights treaties.

\section{B Non-Reciprocity and International Supervision: The Case of Austria v. Italy}

Attempting to identify the precise nature of human rights 'supervisory' systems, beyond merely recognizing that they are directed towards the "protection of the human person', has always been problematic. Various terms are usually employed to describe such systems - including 'implementation', 'monitoring', 'supervision' and 'enforcement' - and all tend to be used interchangeably without any sense that they have distinct connotations for the role of the organ concerned. ${ }^{105}$ If there is a common understanding, however, it is that the processes involved are largely indifferent to the rights or interests of other contracting states - they are not, in that sense, concerned

103 See, e.g., Article 27(3) which requires a state availing itself of the right to suspend the guarantees to inform other states parties of that fact.

${ }^{104}$ Such an idea is doubly reinforced by the fact that the competence of the Commission in relation to inter-state communications is premised upon a mutuality of consent. Article 45(2).

${ }^{105}$ It might be said that, whilst the terms 'monitoring' or 'supervision' suggest that the focus of activity is necessarily upon what happens within each national jurisdiction, 'implementation' and 'enforcement', by contrast, focus on the activities of the supervisory organ. Similarly, whilst 'implementation' suggests something in the nature of a cooperative endeavour, 'enforcement', and to a lesser extent 'monitoring' and 'supervision', are concerned more with taking recalcitrant states to task. 
with the vindication of the rights of states party to the treaty concerned, but merely with the fulfilment of the obligations in question. Human rights 'supervision', therefore, seems to be an activity quite distinct from processes of 'dispute resolution' found in other fora. By the same token, it is clear that several human rights treaties, in addition to containing 'quasi-judicial' mechanisms for supervision, also contain provisions that are more explicitly directed towards inter-state dispute resolution. In some such cases, these may involve the submission of such disputes to the ICJ or to arbitration. In others (and particularly where courts are involved) inter-state petitions may be received by the dedicated supervisory body. ${ }^{106}$ The question is, therefore, whether such processes necessarily affirm the inherently reciprocal structure of the treaties concerned.

The initial assumption, of course, is that reciprocity is a central leitmotif of inter-state dispute resolution and must necessarily play a role in such mechanisms as are found in human rights treaties. A quite different approach to this question, however, was taken by the European Commission of Human Rights in the case of Austria v. Italy. ${ }^{107}$ In this particular case, Austria had complained to the Commission about criminal proceedings brought against six men of German-speaking origin in the South Tyrol. It argued, among other things, that various aspects of the trial were incompatible with the terms of Article 6 of the Convention. Italy objected to the exercise of jurisdiction on the part of the Commission, however, on the basis that, although Italy was party to the Convention at the date of the proceedings in question, Austria was not and had only subsequently ratified the Convention. The Commission rejected Italy's objections on the grounds that the treaty was not, as such, based upon reciprocity. It explained that:

the purpose of the High Contracting Parties in concluding the convention was not to concede to each other reciprocal rights and obligations in pursuance of their individual national interests, but to realise the aims and ideals of the Council of Europe, as expressed in its Statute, and to establish a common public order of the free democracies of Europe with the object of safeguarding their common heritage of political traditions, ideals, freedom and the rule of law. ${ }^{108}$

In light of this overriding purpose, the Commission concluded that:

the obligations undertaken by the High Contracting Parties in the European Convention are essentially of an objective character, being designed rather to protect the fundamental rights of individual human beings from infringements by any of the High Contracting Parties than to create subjective and reciprocal rights for the High Contracting Parties themselves. ${ }^{109}$

The clear purpose of the Commission's remarks in this context was to establish a basis for its own exercise of jurisdiction ratione temporis and to avoid the supposition that, although Italy was bound to respect the rights of the men in question, Austria was unable to seize the Commission of the issue simply because at that particular time

\footnotetext{
106 E.g., European Convention on Human Rights; Inter-American Convention on Human Rights.

107 Application No. 788/60, 4 European Yearbook of Human Rights (1961) 116.

108 Ibid, at 138 .

109 Ibid, at 140 .
} 
it was not a party to the Convention itself. It is quite clear that had it been Austria that was brought before the Commission for the acts in question, the Commission would not have been able to exercise jurisdiction. A strict application of the principle of reciprocity, therefore, would mean that Italy could have relied upon the implicit temporal limitation in Austria's instrument of ratification to exclude the jurisdiction of the Commission in this particular case. The fact of non-reciprocity, therefore, was of critical importance not only for the exercise of jurisdiction by the Commission, but also for how the 'regime' as a whole was to be characterized. ${ }^{110}$

Whilst the full implications of the Commission's approach were never made explicit, one may suppose that certain consequences do follow. First of all, it would seem that in denying the applicability of the concept of reciprocity in this case, the Commission was of the view that the inter-state petition mechanism was simply a means of ensuring compliance with obligations, and did not, in that sense, provide for the vindication of individual state 'rights'. Certainly states had a right to petition the Commission under Article 24, but in so doing they were not attempting to secure their own subjective rights, but were serving something in the nature of a 'public' function. The second conclusion seems to follow from this: that the mechanism was essentially one designed to further the ends of the regime as an institution embodying collective values. All states within the regime, therefore, had a legitimate interest in compliance, but the substance of that legal interest did not provide any need for reciprocal engagement. In some senses, therefore, the mechanism would properly be regarded not so much as one designed for 'dispute resolution' ${ }^{\text {'11 }}$ but rather as allowing for a form of actio popularis for the achievement of certain designated ends.

The approach of the European Commission in Austria v. Italy was subsequently both reinforced and qualified by the European Court in the case of Ireland v. UK. ${ }^{112}$ In that case the Court discussed the implications of Article 1 of the Convention and in doing so, pointed out that the Convention:

comprises more than mere reciprocal engagements between contracting States. It creates, over and above a network of mutual bilateral undertakings, objective obligations ... which benefit from a 'collective enforcement'. ${ }^{113}$

This mechanism of 'collective enforcement' under Article 24, according to the Court 'allows Contracting States to require the observance of those obligations without having to justify an interest deriving ... from the fact that a measure they complain of has prejudiced one of their own nationals'. ${ }^{114}$ Nor was it necessary to show that any particular individual had been harmed by the law or administrative

110 Article 24, for example, provides that states may refer to the Commission 'any alleged breach of the provisions of the Convention', and not merely breaches that involve nationals of the complaining state. See also, in that regard, Application of the Convention (article on the Prevention and Punishment of Genocide), ICJ Reports (1996) para. 34.

111 It is a curiosity that only one Article of the Convention (Article 55) actually refers to the process as one of 'dispute settlement', and this only by way of excluding recourse to other such processes.

112 Ireland v. United Kingdom, ECHR, Series A, No. 25, Judgment of 18 January 1978, 2 EHRR 25.

113 Ibid.

${ }^{114}$ Ibid. 
practice, or that domestic remedies had been exhausted. The legal interest of states, it would seem, derived simply from the fact of being participants in the regime, and committed to the furtherance of the regime's object and purpose. What is significant about the Court's statement, however, is that, in affirming the peculiarities of the Convention in this respect, it did not express the idea of non-reciprocity in the same terms as the Commission before it, or indeed the Inter-American Court subsequently. As the above extract makes clear, although in the view of the Court the Convention benefits from a collective enforcement, and although it creates obligations of an 'objective nature', it does, nevertheless, found itself upon a 'network of mutual bilateral undertakings' based on reciprocity. It is, in other words, still a treaty of the usual form, albeit one whose mechanism of enforcement was not premised upon the normal rules of diplomatic protection. ${ }^{115}$

\section{Form, Purpose or Cognition? The Alternative Identities of the Human Rights Treaty}

Ultimately, there seem to be several different ways of reconciling the issue, the choice among which turns upon several factors including the nature of the values enunciated within the treaty concerned; the understanding of who is, or who is not, a participant in the regime; and finally the relationship between human rights 'regimes' and the perceived structure of international law. The variety of possible approaches to this question may be captured succinctly in three different models that may be identified largely by their dominant paradigm as 'formalist', 'purposive' or 'cognitivist'.

The first approach is largely formalist in orientation, and is one which seems to have prevailed within the ILC at least. Its most coherent exponent is Simma, who explains the nature of human rights treaties in the following way:

On the normative level, the treaties under consideration set forth reciprocal rights and obligations in precisely the same way as their more traditional counterparts. The difference lies in the fact that, in the case of pure social or humanitarian conventions, the mutual rights of the States parties are not accompanied by any material benefits accruing to them. Whereas in cases of agreements regulating genuine inter-State relations treaty obligations have to be accepted and carried out as the conditio sine qua non for the enjoyment of the advantages accruing from the other parties' performance, the standards prescribed by the conventions of the novel type could also be realized unilaterally. That States assume such social or

115 The UK emphasized precisely this point in its comments on General Comment No. 24, supra note 16. Ironically enough, however, in its pleadings before the ICJ in the Reservations Case, the UK took the view that 'this type of convention does not provide for reciprocal benefits between the parties of a tangible character. It provides almost exclusively for the assumption by them of obligations ... not dependent on the assumption of a similar obligation by the other parties... In short, we are in the presence here of absolute obligations, not subject to any considerations of reciprocity at all.' Reservations to the Convention on the Prevention and Punishment of the Crime of Genocide, ICJ Pleadings (1951) 64 and 387-388. 
humanitarian obligations in treaty form in spite of this fact can be explained by the interest each contracting party has in every other party keeping step by accepting identical obligations. To speak of 'community interest' in this regard instead of common interests pure and simple is both unnecessary and ambiguous. ${ }^{116}$

As far as Simma is concerned, then, human rights treaties can be adequately accommodated within the bilateralist framework of standard treaty law. State interests, here, are ever present and simply 'overlapping', or 'intersecting', rather than divergent. Human rights treaties, accordingly, are still founded upon a series of bilateral relationships between contracting parties subject only to the qualification that compliance is not necessarily premised upon that relationship. For Simma, therefore, the claim to non-reciprocity in the case of human rights treaties is largely misconceived: they are only non-reciprocal in the sense that they lack any clear underlying sociological or material exchange, but not insofar as legal reciprocity is concerned.

There is considerable attraction in Simma's analysis from a formal point of view, not least because it negotiates a path between accepting the special characteristics of human rights treaties whilst maintaining the credibility of the existing structures of treaty law. It also explains, quite effectively, the presence within human rights treaties of 'typically contractual' clauses such as those providing for dispute resolution, for 'entry into force' following ratification of a certain number of states, and for unilateral denunciation. That being said, it is not perfect in its capacity to accommodate the variety of textual provisions. It does not explain, for example, why modification by majority decision should be possible, ${ }^{117}$ why contracting states should not be able to prevent the entry into force of the Convention as regards states entering impermissible reservations, or why reciprocity may not be a relevant jurisdictional factor in inter-state disputes (as was evident in Austria v. Italy). But these, it might be argued, are simply minor and inconsequential exceptions that do not detract from the general presumptive framework.

The second approach centres more upon the teleology of the regimes rather than their form, and takes more seriously the notion of non-reciprocity. On this analysis, human rights treaties are properly understood to be concerned with the protection of the legal interests of individuals or groups rather than those of states themselves. They embody (depending upon one's view) either a series of unilateral commitments on the part of participating states as regards individuals or groups falling within their jurisdiction, or a series of 'internationalized constitutional agreements' that seek to establish enforceable legal relations as between public authorities and the individuals in question. ${ }^{118}$ In either case, participating states may be seen to have certain procedural rights in order to effectuate, or protect, the object of that regime, but those rights are not directed towards the pursuit or protection of their own specific legal

116 Simma, supra note 73 , at 401.

117 E.g., Article 50(2) of the Convention on the Rights of the Child (1989).

118 In other circumstances, the dominant example of an 'internationalized constitutional agreement' would seem to be the Dayton Agreement for Bosnia-Herzegovina, 35 ILM (1996) 75. 
interests which are neither present nor relevant. ${ }^{119}$ To turn Simma's analysis around, it may be said that the regimes recognize a form of sociological reciprocity (in the sense that states understand the protection of human rights as being conducive to international peace and good order ${ }^{120}$ ), but do not necessarily invoke or enunciate any notion of legal reciprocity.

This analysis draws largely upon a 'cosmopolitan' or 'liberal' vision of international legal relations ${ }^{121}$ that denies the exclusivity (or perhaps the reality) of state corporate personality and the sharp delineation between internal and external spheres of activity. It emphasizes rather the fundamental centrality of individuals as legal actors and concerns itself with the complex interdependence between national and international legal orders. The benefits of this approach are to be found in the way it more closely equates the relevant legal interest with the identity of the 'rights holders' under the agreement (i.e. the individuals or groups in question), and in the way it more faithfully adheres to the logic of the regime (i.e. to effectuate 'domestic change' rather than 'international coordination'). Furthermore, insofar as this model privileges the individual, or group, rights framework, it also provides better justification for automatic succession to human rights treaties: succession to obligations under such treaties would not, if viewed in this way, have any necessary third-party effect, and would, if anything, be necessitated by the international character of the rights in question. Clearly, however, to understand human rights treaties in this way would amount to a significant departure from the general 'contractual' paradigm, and would necessarily entail a re-evaluation of the role of individuals in the law-creative process.

The third approach, and that which draws more obviously upon the constitutive nature of legal 'regimes', ${ }^{122}$ is to view human rights treaties as embodying certain 'collective values' (and not simply 'common values' to use Simma's distinction) which both define and transcend individual states' legal interests. Since the treaty, according to this view, is the product of coordinated action by states acting in concert, the substantive values and protected legal interests embodied also partake of this character. In ratifying the treaty, therefore, states assume obligations not in relation to each other state $u t$ singuli, but to all other participating states as a collective. ${ }^{123}$ Each

119 Cf. Fitzmaurice, who comments that '[c]ertain kinds of multilateral treaties do not involve direct benefits for any of the participating countries. The benefit is of a general character arising from participation in a common cause for the general good.' Fourth Report on the Law of Treaties, UN Doc. A/CN.4/120, 2 Yearbook of the International Law Commission (1959) 54.

${ }^{120}$ This idea was initially propounded by Kant, 'To Perpetual Peace: A Philosophical Sketch' [1795] in Perpetual Peace and Other Essays (Humphrey trans. 1983) 107. It has since been endorsed by e.g. F. Teson, A Philosophy of International Law (1998) 9-14; Doyle, 'Liberalism and World Politics', 80 APSR (1986) 1151; Rummel, 'Libertarianism and International Conflict', 27 Journal of Conflict Resolution (1983) 27.

121 See, e.g., Slaughter, 'International Law in a World of Liberal States', 6 EJIL (1995) 503; Teson, supra note 120.

122 On 'regime theory' generally, see A. Hasenclever, P. Mayer and V. Rittberger, Theories of International Regimes (1997). See also Simma, 'Self-Contained Regimes', 16 Netherlands Yearbook of International Law (1985) 111.

123 One way of explaining this framework without reference to the idea of a contractual bargain, may be by resort to the notion of erga omnes obligations. Cf. Simma, supra note 73, at 370. 
state, therefore, may be seen to have a legal interest in the performance of the obligations concerned, and it is to that end that inter-state petition mechanisms are directed. This may seem to indicate a return to the type of relational structure that is expressive of the idea of reciprocity, ${ }^{124}$ but the important factor is that the legal interest possessed by states is a derivative, and not exclusively personal, one. The regime, in other words, is seen in 'constructivist' terms, ${ }^{125}$ as being constitutive of the nature and identity of those state interests rather than simply being a product of a mutual exchange between individual states. Individual state interests, in other words, are entirely bounded by (and constituted within) the interests of the regime as a whole, and exist only insofar as they correspond with that of the collective.

Given the emphasis, in this third approach, upon the nature of the regime as the source of legal interests, it would seem to follow that, whatever the formal position in 'treaty law', it is the regime's institutions that must play the dominant role in determining the treaty's application and effect. The effect of reservations or the question of compliance, in other words, can only be determined by the centralized institutions that are constitutive of the regime, and are not matters on which individual states may (legally speaking) take a different view. The obvious objection, of course, is that when one begins with an individualist methodology that is focused exclusively upon state activities (and particularly state consent), one may always deny the 'reality' of the 'collective'. Such an objection, however, is not one that can easily be deployed without warranting a re-examination, in turn, of the nature of state, or governmental, competence.

Ultimately, each of these three approaches as to the nature and form of human rights treaty regimes draws upon particular facets of those institutions: first, that they are treaties (the formal), secondly, that they embody 'human rights' (the purposive) and, thirdly, that they institute some form of discrete legal regime (the cognitivist). What seems apparent, however, is that an emphasis on any one facet will necessarily prejudice the others. To say that they are 'simply' treaties, is to say that the 'rights' embodied are little more than epiphenomena (conclusions that may be derived from the existence of state obligations), and that their dominant rationale is the protection of pre-existent state interests. Similarly, to say that they are concerned primarily with the protection of human rights, is to say that their legal form is secondary and their correspondence with other legal interests (sovereignty, territorial integrity) largely accidental. Current practice, it seems, attempts to meld these competing conceptions, ${ }^{126}$ and the resulting tension is very much evident in the contradictions outlined above. On the issue of reservations, for example, each approach offers a radically

${ }^{124}$ See Kratochwil and Ruggie, 'International Organization: A State of the Art or an Art of the State', 40 International Organisation (1986) 753.

${ }^{125}$ For 'constructivism' in general, see, e.g., Wendt and Duvall, 'Institutions and International Order', in E.-O. Czempiel and J. Rosenau (eds), Global Changes and Theoretical Challenges: Approaches to the World Politics for the 1990s (1989) 51.

${ }^{126}$ It is characteristic, for example, to suggest that human rights treaties simultaneously embody both state legal interests and individual legal interests: see e.g. H. Lauterpacht, An International Bill of the Rights of Man (1945). 
different answer. For example, in determining the effect of a putatively 'incompatible' reservation, an emphasis on the instrument's form might suggest that compatibility should be determined by unanimous consent. An emphasis upon its existence as a 'regime', by contrast, might suggest that the matter should be determined by the (presumptively) competent institutions, while an emphasis on teleology might suggest that the benefits of universal ratification outweigh the disadvantages of partial commitment. That no one approach is fully explanatory, however, reflects not only the evident complexity of the treaties themselves, but also the apparent tensions that are maintained within existing conceptions of international law.

\section{Conclusions}

The purpose of this article has been to explore, through the particular optic of human rights treaties, a generic issue that, in formalist terms, concerns the putative relationship between what is referred to as 'general law' and a lex specialis. This relationship is one overtly concerned with a simple question of substance: to what extent can the general framework of treaty law be applied, without exception, to human rights treaties among other forms of treaty? It is, however, also concerned with more fundamental issues that go beyond simply a question of textual exegesis. Whatever model employed to describe the relationship, necessarily invokes a particular understanding as to the nature of the international legal order, and in doing so reflects upon certain divisional suppositions that characterize that understanding: included here are the divisions between 'law' and 'legal obligation', between the 'general' and the 'specific', between 'public' and 'private' law, and between the so-called primary and secondary rules that underlie a common conception of law. ${ }^{127}$

To put the matter starkly, one may ask what is involved in insisting that the framework of general treaty law applies as regards human rights treaties? The answer, it would seem, is not simply an appeal to terminological accuracy (i.e. that conventions, covenants, charters or protocols are indeed 'treaties'), nor a concern to exclude any other status that might be given to their content. Rather, it is an appeal to the apparent integrity of 'general international law' as being a cohesive, unitary and all-embracing phenomenon which is itself dependent upon the implicit delineation between different 'forms of law'. We are asked, it seems, to differentiate in a hierarchical sense between the generality of treaty law and the specifics of particular treaties, and assume thereby the existence of a differentiation between secondary rules of structure and the primary rules of 'behaviour'. We are expected, furthermore, to understand (in nothing more than an intuitive sense it may be said) how the object of our attention falls within the framework of this understanding: the Vienna Convention on the Law of Treaties, after all, is no more than simply a treaty in its form, even if its content is regarded as being something 'other'.

127 E.g., H. Hart, The Concept of Law (1956) 77-96. See also Combacau and Alland, “"Primary” and "Secondary" Rules in the Law of State Responsibility: Categorizing International Obligations', 16 Netherlands Yearbook of International Law (1985) 81. 
If there is an explanation for this attitude, it is best illustrated by Weber's approach as regards the necessary development of formal rationality and functional specialization in modern bureaucratic societies, ${ }^{128}$ in which he views the development of law as being marked by an ever increasing complexity of legal forms and processes. This increased complexity, far from signalling the imminent demise of the system, is actually the hallmark of its maturity: it is part of the process of 'bureaucratic rationalization' that sees the replacement of 'substantive rationality' (concerned with ethical, prudential or aesthetic choices of a non-legal character) by a systemic 'formal rationality' that allows cases to be decided by logical deduction from existing legal rules and concepts constituting a gapless system. ${ }^{129}$ The development of law, therefore, is seen primarily in terms of its 'specialization', which itself is a corollary of the system's increasing capacity to control or eliminate arbitrariness and to render more effective the achievement of certain socially desirable ends. ${ }^{130}$ Legal development (qua specialization), in other words, is a product of the increasingly intensive manner in which the existing general principles are applied and developed in particular contexts.

The vision of international law engendered by this model of 'legal development' is far from perfect. Not only does it entirely gloss over the enduring problem of legitimacy (under what conditions may the 'general structure' come into being?), but it also fails to explain how the law may effectively respond to the changing structures, attitudes and interests of the society within which it operates. If the process is entirely deductive (as is suggested), the general framework would establish the rational boundaries of development of the lex specialis which could not be broached without discarding its claim to be formally rational, and without stepping 'outside the law' so to speak. The field of specialism would, therefore, be entirely constrained by existing suppositions as to the 'nature' of international law as a whole and would, itself, be incapable of influencing the general shape or tenor of those suppositions. In the triumph of 'law', in other words, would be found the seeds of its own destruction — law would become effectively moribund and incapable of change.

Even if 'deductive reasoning' has its limits, the answer is not to be found in a resort to inductive reasoning, ${ }^{131}$ or indeed to some qualified 'dialectic', but rather in the acceptance that the formal differentiation between such 'forms of law' are largely hypothetical and, in any case, not of critical importance for our commitment to, or understanding of, international law. Indeed, once one accepts that the boundaries of international legal activity are not determined a priori, by reference to any particular jurisdiction, power, competence or capacity, and that its utility is not found solely in

128 M. Weber, Economy and Society (1978) 85-86, 225-226, 956-959 and 975.

${ }^{129} \mathrm{Ibid}$, at 656-657.

${ }^{130}$ See generally D. Milanovic, Weberian and Marxian Analysis of Law (1989) 37-41.

${ }^{131}$ Inductive reasoning follows a similarly flawed pattern: if the 'general law' is simply the product of points of commonality that are found in the various fields of specialism, it would not, in that sense, constrain or control the development of specific norms, principles or processes and would continue to have salience only so long as the fields of specialism were themselves compatible one with the other. Specialization, in other words, would slowly undermine the claim to unity of the law as a whole. 
the preservation of the interests of elites, oligarchies or autocracies, it becomes less problematic to accept that legal regimes may come to be created and develop independently of a framework that insists that the 'inter-state' compact is the only legal form worthy of mention. It is certainly true that 'treaty law' has a general utility and that human rights treaty bodies may, from time to time, refer to certain of those 'governing principles' (e.g. pacta sunt servanda), but that is a far cry from any supposition that the instruments in question can only be understood within that framework, or indeed that they have no salience otherwise. Importantly, it may be argued that, since human rights treaties not only serve to place certain limits upon the nature and scope of governmental authority but also contribute to the development of a justifiable basis for that authority (albeit in no unproblematic manner), they cannot therefore simply be regarded as the accidental data of an otherwise disinterested legal system. Whatever one's term for them, to say that they are 'only treaties' is merely to place them within a highly contingent set of understandings as to the nature of international legal relations. 
